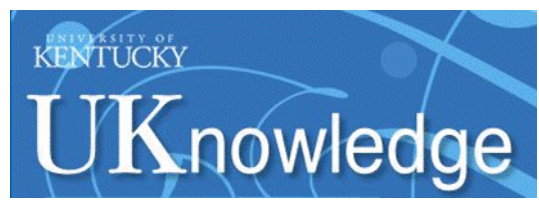

University of Kentucky

UKnowledge

Microbiology, Immunology, and Molecular Genetics Faculty Publications

Microbiology, Immunology, and Molecular

Genetics

2015

\title{
A Therapeutic Approach for Senile Dementias: Neuroangiogenesis
}

Charles T. Ambrose

University of Kentucky, cambros@uky.edu

Follow this and additional works at: https://uknowledge.uky.edu/microbio_facpub

Part of the Geriatrics Commons, Molecular Genetics Commons, and the Neurology Commons

Right click to open a feedback form in a new tab to let us know how this document benefits you.

\section{Repository Citation}

Ambrose, Charles T., "A Therapeutic Approach for Senile Dementias: Neuroangiogenesis" (2015).

Microbiology, Immunology, and Molecular Genetics Faculty Publications. 110.

https://uknowledge.uky.edu/microbio_facpub/110

This Article is brought to you for free and open access by the Microbiology, Immunology, and Molecular Genetics at UKnowledge. It has been accepted for inclusion in Microbiology, Immunology, and Molecular Genetics Faculty Publications by an authorized administrator of UKnowledge. For more information, please contact

UKnowledge@lsv.uky.edu. 
A Therapeutic Approach for Senile Dementias: Neuroangiogenesis

Digital Object Identifier (DOI)

https://doi.org/10.3233/JAD-140498

Notes/Citation Information

Published in Journal of Alzheimer's Disease, v. 43, no. 1, p. 1-17.

(C) 2015 - IOS Press and the author

The copyright holders have granted the permission for posting the article here.

The document available for download is the author's post-peer-review final draft of the article. The final publication is available at IOS Press through https://doi.org/10.3233/JAD-140498.

This article is available at UKnowledge: https://uknowledge.uky.edu/microbio_facpub/110 


\section{ABSTRACT (234 words)}

Alzheimer's disease (AD) and related senile dementias (SDs) represent a growing medical and economic crisis in this country. Apart from cautioning persons about risk factors, no practical, effective therapy is currently available. Much of the recent research in AD has been based on the amyloid cascade theory. Another approach assumes a vascular basis for the senile dementias. This paper presents evidence from a score of studies that cerebral capillary density (CCD) declines during old age in animals and people and also in AD. Neuroangiogenic (NAG) factors initiate and maintain capillaries in the brain. Thus a waning level of these factors and the ensuing declining CCD would lead to local areas of reduced oxygen and glucose and result in impaired synaptic and neuronal function. The NAG hypothesis developed here proposes that the age-linked decline in CCD is a terminal condition in SDs, including many cases of AD. This age-linked decline is independent of any other of the various pathologies proposed as causing AD and listed in Table 1. Waning NAG factors would render the SDs a deficiency condition, somewhat like falling androgen levels in aging males. A logical corollary of this hypothesis is that chronic replacement therapy with recombinant forms of NAG factors may arrest the agelinked decline in CCD and prevent further loss of memory and mental deterioration. A transnasal route of therapy seems the most practical one for general use in the large aging populations.

\section{KEY WORDS:}

neuroangiogenesis, cerebral capillary density, senile dementia, Alzheimer's disease, cognitive impairment 


\section{A THERAPEUTIC APPROACH FOR SENILE DEMENTIAS: NEUROANGIOGENSIS}

\section{INTRODUCTION}

The absence of an effective treatment for Alzheimer's disease (AD) and other senile dementias continues notwithstanding the many thousands of studies on these medical conditions during the past half century. The diverse range of these investigations is shown in Table 1. Recently, Jack C. de la Torre employed "evidence based meta-analysis from standardized control studies" to determine whether the cause of AD could reasonably be ascribed to any of seven "more cited hypothetical proposals" [1]. The seven are indicated with an asterisk in the Table 1. Koch's postulates were used as the framework for his assessments. De la Torre judged none of the seven completely satisfactory, although he found "partial positive support" for oxidative stress and the various vascular hypotheses. Dominating investigations over twenty years has been the amyloid cascade theory of Hardy and Higgins $[2,3]$. Numerous clinical trials based on it and other proposed etiologies of AD have been carried out, but "none of which has yet achieved robust slowing of cognitive decline" [4]. A recent paper on AD suggested the obvious that "New therapeutic approaches are desperately needed" [5].

In medicine, the usual response to an unresolved clinical problem is to say that "more research is required." However, an examination of the literature on $\mathrm{AD}$, other senile dementias, and aging may itself be productive. Buried there and in unrelated reports on anatomy and 
pharmacology are abundant data showing that a reduction in the cerebral capillary bed occurs in rats and mice during old age and commonly begins in people during late adulthood. This reduction has also been found in subjects with $\mathrm{AD}$, most of whom, of course, were aged. Various changes in the capillaries discussed later have led investigator to suggest that a defective cerebral capillary bed could cause synaptic and neuronal dysfunction and ultimately produce abnormalities in memory, behavior, and general cognition.

The thesis of this essay is that the age-linked reduction in capillary numbers in various areas of the brain contributes to senile dementias, including possibly also AD. This idea is further developed in the neuroangiogenic (NAG) hypothesis, which proposes that the reduced cerebral capillary density (CCD) is due to the age-linked declining levels of vascular trophic factors in these areas. This hypothesis thus points to an untried therapeutic approach - restoring levels by administering recombinant neuroangiogenic factors.

Figures cited for the recent and anticipated incidence of AD in the United States are 5.4 million in 2011, 7.7 million in 2030, and 16 million in 2050 [6]. This growing crisis involves more than this one eponymic disease (AD) and includes the group termed vascular dementias (VaD) [6]. They overlap so much in clinical features and neuropathology that "a rigid distinction between $\mathrm{AD}$ and $\mathrm{VaD}$ is no longer tenable" [7]. Many others concur [8-11]. In this essay, both will often be considered collectively as the senile dementias (SDs) in order to emphasize a common vascular pathology. The generic term senile dementia has been viewed as a symptom complex of sixty disorders, of which $50-60 \%$ are $\mathrm{AD}, 10-20 \% \mathrm{VaD}$, and the rest include brain tumors, paresis of neurosyphilis, AIDS, toxins, and metabolic disorders. Again, in this essay, the term "senile dementia" includes $\mathrm{AD}$ and $\mathrm{VaD}$ but none of the rest. 
The NAG hypothesis is not a rival to various theories about the etiology of AD, such as amyloidopathy, neurotransmitter deficits, multiple microinfarcts, and others listed in Table 1. This hypothesis proposes that in $\mathrm{AD}$, an age-linked reduced cerebral capillary circulation may occur secondarily (or be in addition) to other brain pathology. Also, in many elderly persons devoid of any significant evidence of $\mathrm{AD}$, a defective microcirculation alone may be a primary cause of synaptic dysfunction and/or neuronal loss and the ensuing cognitive decline.

This essay focuses first on the cerebral microcirculation and points out an error accounting for some discordant capillary density data in the literature. A restatement of the NAG hypothesis is followed by information on age-linked levels of angiotrophic factors. The concept of neurological/cognitive reserve is introduced and may explain a clinical-histological paradox in AD. The concluding sections center on the potential treatment of SDs with NAG factors.

\section{CEREBRAL VASCULAR STUDIES}

In 1984 Arnold B. Scheibel wrote that in persons with "presenile and senile dementia of the Alzheimer type ... the diminished cerebral blood flow $[\mathrm{CBF}]$ is more or less proportional to the degree of mental impairment ... loss of verbal ability ... [and] verbal memory decrease" [12]. $\mathrm{CBF}$ and cerebral hypoxia have been implicated in SDs by many investigators [13-22]. A reduced $\mathrm{CBF}$ has been blamed for a lowered learning ability in older rats [23,24]. Such measurements reflect conditions of both the large afferent vessels largely outside the brain and cerebral capillaries in the brain parenchyma.

Upstream. Chronic impairment of the circulation may occur in arteries and arterioles altered by risk factors, such as atherosclerosis, hypertension, cardiac arrhythmias, carotid artery 
disease, smoking, diabetes, etc. [22,25,26]. In 2004, de la Torre advanced a vascular hypothesis in which such risk factors sequentially induce brain hypoperfusion, a neuroglial energy crisis, and ultimately neurodegeneration beginning with mild cognitive impairment and ending with vascular dementia $(\mathrm{VaD})$ and $\mathrm{AD}[27]$.

Downstream. Investigators considering a microvascular basis for AD have focused on the blood brain barrier or qualitative abnormalities in the cerebral capillaries [28-34]. Several groups proposed that amyloid deposits in small cerebral vessels could impair the delivery of essential nutrients to cerebral neurons [35,36]. Over the years Zlokovic has advanced multifactorial hypotheses, which invoked faulty clearance of amyloid $\beta$ peptide $(A \beta)$ across the blood-brain barrier, oxidative stress by neurotoxic $\mathrm{A} \beta$ peptides, and other processes -- all ultimately leading to synaptic and neuronal dysfunction [37].

As early as 1974, Hachinski et al. proposed that multiple cerebral infarcts produce mental deterioration in the elderly [38]. Three reviews in 2012 summarized many reports associating cognitive impairment with cerebral microinfarcts [39-41]. Their etiology has been variously ascribed to an embolic origin, intermittent focal ischemic episodes, or cerebral amyloid amyloidopathy [41]. Cullen et al. related amyloid plaque and tangle densities to microhemorrhages and cognitive loss [42].

Scheibel prefaced his article on aging and dementia cited above with "A neuron is no better than the vessel that nurtures it" [12]. Apart from the microhemorrhages above noted, cerebral microvascular abnormalities in $\mathrm{AD}$ have often been described in picturesque terms (see below, Section 3). Largely overlooked have been the age-linked decline in the number of cerebral capillaries. While amyloid deposits, microinfarcts, and microvessel distortions are 
rather easy to observe and count, cerebral capillary density (CCD) has been until recently more difficult to measure (see later, Section 4).

\section{INCREASED CEREBRAL CAPILLARY ABNORMALITIES}

In aged persons. In 1873, three decades before Alois Alzheimer described the first case of $\mathrm{AD}, \mathrm{J}$. Batty Tuke had reported that the brains of many insane persons were full of deformed blood-vessels showing "undue straightness, tortuosity, and kinking” [43]. Although their ages were not stated, many of these institutionalized patients were likely elderly and some may have been cases of AD. In 1967, a century after Tuke's report, Hassler observed glomerular loop formations, vascular bundles, and vascular wickerworks in the arteries of brain slices from the frontal and occipital lobes [44]. In 231 autopsies selected at random, he found these changes to be common the brains of persons over age 65 but uncommon in those younger than age 50 . He theorized that such "deformities are responsible for the slow cerebral circulation in senile dementia." In 1978 Ravens described similar vascular alterations in senile brains at the level of small arteries, arterioles, and pre-capillaries [45]. Wilkinson et al. also ascribed the reduced CBF to vascular resistance in the deformed capillaries [46].

In $\boldsymbol{A D}$. In a 1993 article entitled "Can disturbed brain microcirculation cause Alzheimer's disease?," de la Torre and Mussivand focused on cerebral capillaries distorted by amyloid deposits and a thickened basement membrane [35]. They cited 13 reports of cerebral vascular abnormalities found at autopsy in $\mathrm{AD}$ and other forms of dementia and reasoned that any disturbed blood flow would reduce delivery of oxygen and glucose to cerebral neurons and possibly lead to AD. A decade later, Bailey et al. described various distortions of microvessels in AD brains -- string vessels, glomerular loop formation, and twisted or tortuous vessels -- and 
reiterated the view that microvascular changes "may precede the cognitive decline and neuropathological changes of AD” [47].

Among the 13 reports mentioned above was one by Fisher et al., who had observed a striking increase in tortuous and looped arterioles and capillaries in brain sections of AD subjects versus controls [48]. The average counts for distorted capillaries in 6 control subjects (ages 2390) and 16 subjects with AD (ages 75-92) in various areas of the brain were as follows for controls vs. aged: prefrontal cortex: 213 vs. 657, basal forebrain: 167 vs. 916, hippocampus: 230 vs. 867 , and motor/sensory cortex: 218 vs. 908 . The same study revealed a "statistically significant reduction in the vascular net density" (reviewed in the next section) and thus suggests a temporal connection between emerging capillary distortions and a later declining cerebral capillary density.

\section{DECREASED CEREBRAL CAPILLARY DENSITY (Tables 2 and 3)}

CCD in aged rats. In the 1920s Edward Horne Craigie pursued studies on quantitative morphometry of rat brain capillaries. He measured the length of each capillary segment present in a fixed number of adjacent brain sections and interpreted the sum of the lengths found in this volume of brain tissue as an index of the cerebral capillary density. In aged rats he found decreased CCD in two areas of the cerebral cortex - regio insularis and regio temporalis [49]. For example, the CCD in the regio insulatis of five-month old rats was $856 \mu$, while that of 13month old rats was only $638 \boldsymbol{\mu}$. In the regio temporalis the comparable values were $958 \mu$ and $880 \mu$. See Table 2. (Here and below in comparisons of CCDs, the average figure for the older members of a set is in bold italicized type.) 
Other early investigators counted capillaries by various systems which yielded numbers unique to their particular study and comparable only within it. Later studies have employed computerized image analysis [50-52]. For example, Amenta et al. used alkaline phosphatase histochemistry with an ASBA image analyzer (Leica, Cambridge, UK). They determined the sum of capillary lengths in $500 \mu \mathrm{m}^{2}$ sections in the frontal cortex of 12- and 27-month old male Wistar and found values $190 \mu \mathrm{m}$ and $\mathbf{1 6 8} \boldsymbol{\mu m}$, respectively [53]. In this same investigation, the older rats had comparable capillary reductions in the occipital cortex and other brain areas. Table 2 of this essay lists age-related reductions in CCD from eleven studies in rats and one each in mice and Macaque monkeys [34,45,49,54-63].

CCD in aged persons. Reduced CCDs have also been reported in aged persons. In Table 3, the top five sets of data (\#14-18) illustrate the capillary density in human brains at different ages in different areas: frontal and temporal cortices, paraventricular nuclei of the hypothalamus, and the hippocampus [64-69]. For example, Mann et al. reported the "mean capillary measure" in the frontal cortex of mentally normal subjects. In six adults ages $26-58$ the average value was $965.6 \mu \mathrm{m} \pm 132$, while in nine older subjects age $76-96$ it was $782.6 \mu \mathrm{m} \pm 56$ [64]. The other four reports in this table show a comparable reduction with aging. Parenthetically, the microcirculation in the aged retina parallels that in the aged brain. Kuwabara and Cogan noted "a loss of endothelium ... in the capillaries of the peripheral retina in persons past middle life (50 years)" [70].

$\boldsymbol{C C D}$ in $\boldsymbol{A D}$. In Table 3, data in the bottom five sets of figures (\#16-20) indicate decreased CCDs in the brains of persons with $\mathrm{AD}$ compared with other age-paired normal controls [47,66-69]. For example, Fisher et al. found in the basal forebrain of six normal subjects age 23-90 an average "vascular density index" of 86.8, while sixteen persons with Alzheimer's 
disease, age 76-92 yielded an index value of 42.7 [47]. Kitaguchi et al. measured the cerebral capillary density for six controls (age $74 \pm 4$ ) and eight AD subjects (age $79 \pm 12$ ) in two areas. The control and $\boldsymbol{A D}$ values were, respectively, 28 and 21 in the frontal cortex and 28 and 20 in the parietal cortex [69].

Kitaguchi's study also reported that the average weight of the control group brains was $1244 \mathrm{~g} \pm 57$, while that of the AD brains was only $1020 \mathrm{~g} \pm 11(\mathrm{p}<0.05)$. Because of significant brain atrophy in the $\mathrm{AD}$ group, the authors concluded that the actual reduction in the capillary density "may be more severe" - i.e., less than the above AD values of 21 and 20.

\section{POTENTIAL ERRORS IN CCD MEASUREMENTS}

As suggested above and noted by others, cerebral atrophy/shrinkage may mask capillary loss and represents a source of error when comparing CCD measurements in young and old brains $[45,66]$. A simple formula, $\mathbf{C C D}=\mathbf{N} / \mathbf{V}$, will illustrate the issue. $\mathbf{C C D}$ is determined from a particular capillary count $(\mathbf{N})$ within a fixed volume of brain tissue $(\mathbf{V})$. If $\mathbf{V}$ is reduced as a result of shrinkage and $\mathbf{N}$ stays unchanged, then $\mathbf{C C D}$ will appear falsely high. Neglecting to consider brain atrophy may explain why some studies have reported no reduction in CCD with aging, "nonsignificant trends," or even increased CCDs [71-73]. Cortical volume shrinkage has also been extensively discussed in papers concerning neuron numbers in normal aging and AD [74-77]. The parameters of such shrinkage are discussed below.

Brain shrinkage in aged rats. Smith reported the brain volume in rats of middle $v s$. old age. The average volume of the left hemisphere of one-year old rats is $226.6 \mathrm{cc}$ and of two-year olds is 205.6 cc. (9\% loss) [78]. Wilkinson et al. concluded that the age-related changes in the vasculature of the rat cerebral cortex reflect parenchymal atrophy and are "not uniformly 
distributed throughout the cortex" [45]. Others have confirmed that the percentage shrinkage varies in different regions of the brain [75,76,79-82]. This variation may account for Craigie's finding in aged rats a reduced average capillary density in two areas of the cerebral cortex but not in three others, where shrinkage may have occurred and yielded falsely elevated values [49].

Brain shrinkage in aged persons. Appel and Appel reported that the mean weight of 2080 (sic) non-lesioned human brains decreased by $11 \%$ between the ages 25 and 96 [83]. Smith determined that the volume of one hemisphere measures on average at age 30 years $281 \mathrm{cc}$ and at age 60 years $255 \mathrm{cc}$. (9\% loss) [84]. Jernigan et al. found volume loss between the ages of 30 and 90 to be $14 \%$ in the cerebral cortex, $26 \%$ in the cerebral white matter, and $35 \%$ in the hippocampus [85]. Age-related shrinkage of the hippocampus has been noted by others [86-88].

\section{THE NEUROANGIOGENIC (NAG) HYPOTHESIS}

In a 2010 paper, I proposed that the remarkable coordinated finger/hand/foot dexterity displayed by concert pianists was due to additional synaptic connections in the primary motor cortex supported by an increased local capillary density, which in turn was initiated and maintained there by local neuroangiogenesis [89]. I am not aware of any modern histological or imaging studies on the brains of highly proficient pianists. However, in right-handed string musicians "the cortical representation of the fingers of the left hand ... [is] larger than that in controls" [90]. Also magnetic resonance imaging reveals that very proficient jugglers develop in their mid temporal area an expanded gray matter volume which persists enlarged so long as they maintain this skill [91]. Similarly, London taxicab drivers show an increased volume of gray matter in the posterior hippocampus during their years of continued mastery of the city's 25,000 streets but not after their retirement [92]. These transiently expanded areas of gray matter likely 
reflect the sequence of increased synaptic connections supported by local microcirculation induced by an augmented neuroangiongenesis, as I proposed for the motor cortex of concert pianists. There are supporting data for this sequence in animal studies, as reviewed elsewhere [89]. Interest in this area alerted me to the research of Craigie and others showing a waning $C C D$ in aged animals. These led me logically to reports of older persons in whom the CCD had declined - specifically, those with AD and senile dementia.

From this study of the neurological literature came the NAG hypothesis, which concerns SDs in general. The hypothesis involves the two key ideas introduced earlier: 1) the age-related decline in cerebral capillary density in certain areas of the brain and 2) reduced levels there of neuroangiogenic factors. Thus SDs may be viewed as a deficiency disorder - analogous to low testosterone in some older men, for whom androgen therapy is corrective. And as alluded earlier, this hypothesis infers a specific therapy for SDs - i.e., exogenous NAG factors administered chronically to aging persons $[93,94]$.

The NAG hypothesis also suggests that an age-associated down-regulation of genes coding for these factors varies in different parts of the brain and thus may direct where local CCD decline first occurs and later continues. This determines the course and character of senile dementia in a given person -- for example, a weakened declarative memory (hippocampus, etc.) or disturbed emotions (amygdala) or impaired executive functions (prefrontal cortex, temporalparietal association cortices), etc. Senile dementia commonly begins with memory loss and later emotional and personality changes but not always in this order [95]. Brun and Gustafson described a common pattern of "amnesia, aphasia, apaxia, spatial dysfunction, and agnosia" [96]. Motor and sensory functions are not commonly affected early in the course of AD unless infarcts occur [97]. 
Relevant here is a view about cerebral capillaries which is the reverse of the role given them in the NAG hypothesis. Again, the hypothesis proposes that the age-linked reduction of these capillaries leads to a local deficiency of glucose and oxygen and to the subsequent neuronal impairment/death and synaptic dysfunction. A different view is that in AD the death of neurons (from various causes) would lessen the local demand for oxygen and glucose and account for a reduced microcirculation. Capillaries are formed and maintained by angiogenic factors. I do not understand the biological mechanism by which a lessened demand could reduce neuroangiogenesis. In cases of senile dementia not involving AD (and neuronal death) but due to defective synapses there is reduced CCD. Also, capillary density declines with age in other tissues, as discussed later in Section 8. But this controversy over the fate of capillaries in the brain seems moot in light of the therapy proposed by the NAG hypothesis. Regardless of whether a waning CCD is a primary or secondary event in senile dementias, a reduced capillary density may be restored by the administration of exogenous, recombinant NAG factors.

\section{ANGIOGENESIS IN GENERAL}

In higher animals, angiogenic/endothelial trophic factors are responsible for vasculogenesis (new blood vessels from angioblasts) during early development and for angiogenesis (new capillaries from preexisting vessels) later in life. Details about the factors have been amply reviewed elsewhere [98-103]. Their individual names indicate their target or their cellular origin. A major one is the vascular endothelial growth factor (VEGF), which will be mentioned frequently later in this essay [104]. A review on angiogenesis by Felmeden et al. listed the major groups of growth factors involved as vascular (VEGF-B, -C, -D, -E), fibroblast (FGF-1, -2) and angiopoietin (-1 \& -2), but other may contribute - e.g., placental growth factor 
(VEGF-A), platelet derived growth factor (PDGF), transforming growth factor (TGF $\boldsymbol{\beta}$ ), insulin like growth factor (ILGF), and others [105]. Krupinski et al. identified the three most important trophic factors "especially relevant to brain angiogenesis" as the vascular endothelial growth factor (VEGF), endothelial cell growth factor- $\boldsymbol{\beta}$ (ECGF $\boldsymbol{\beta})$, and transforming growth factor- $\boldsymbol{\beta}$ (TGFß) [106]. Other factors and their mechanism have been reviewed elsewhere [107].

As will be noted in a later section (\#9), comparable measurements of NAG factors in the brains of mature vs old animals and adult vs. aged persons are not yet available. But direct evidence for angiogenesis declining with age has been found in muscles of rabbits and mice by Rivard et al. [108]. A summary of this work follows because of its relevance to the NAG hypothesis.

\section{ANGIOGENESIS IN MUSCLES}

Rivard et al. investigated "the hypothesis that angiogenesis is impaired as a function of age" [108]. Local ischemia in areas throughout the body stimulates angiogenic factors present to expand the capillary circulation there. The authors made one hind limb ischemic in young and old laboratory animals by resection of the femoral artery and at a later time measured the capillary density in the affected leg muscle. They used alkaline phosphatase to stain capillaries in muscle sections prepared from six young rabbits (age 6-8 months) and seven old rabbits (age 4-

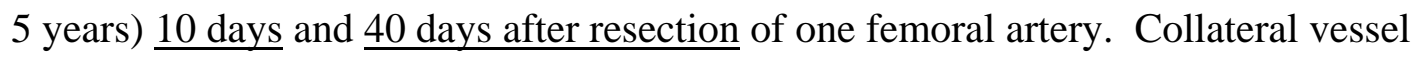
development was reflected in angiographic scores, which on Day 10 and Day 40 were for the young 0.32 rising to 0.68 and in the old 0.43 rising to $\mathbf{0 . 4 8}$. In summary, on Day 10 scores "were similarly low" for both age groups $(0.32$ and 0.43$)$ but by Day 40 had risen to 0.68 in the young rabbits but only $\mathbf{0 . 4 8}$ in the old. Also on Day 40, the average capillary count per $\mathrm{mm}^{2}$ for the 
young rabbits was 170 and for older ones was only $\mathbf{1 3 0}$, indicating a lower level of angiogenesis in the older animals. (The data cited above and below have been extrapolated from Figure 4E \& 4F and 5G \& 5H of the Rivard paper.)

In a comparable study in mice, unilateral hind limb ischemia was created in young and old animals. Capillaries of muscle sections were stained by an immunohistochemical method using CD31, an endothelial cell adhesion molecule. At 28 days after surgery, the average capillary density was 710 for the 12 -week old mice and only $\mathbf{3 5 0}$ for the 2 -year old ones. The above data show decreased capillaries in the muscles of both aged rabbits and mice vs. those in young animals. These findings in leg muscles parallel the data in Tables 2 and 3 concerning CCDs in the brains of older animals and aging people.

The authors also measured VEGF mRNA expression in ischemic hind limbs and found that it was reduced in the muscles of both old rabbits and old mice compared with levels observed in young controls. This reduction is that expected for NAG factors in the brains of some older persons with impaired cognition.

Finally, in this study by Rivard et al., 14 rabbits with unilateral hind limb ischemia (seven 6-8 months old and seven 4-5 years old) were injected with recombinant human vascular endothelial growth factor (rh VEGF) on postoperative day 10 via the iliac artery of the ischemic limb. The average capillary densities of young and old rabbits were determined on Day 10 (just before treatment) and on Day 40. Among the young rabbits the values were 170 (on Day 10) vs. 280 (on Day $40=64 \%$ increase). Among the old rabbits they were 130 (on Day 10) vs. 190 (on Day $40=46 \%$ increase). Thus, in both age groups the administration of VEGF increased the capillary density. The authors commented that "Advanced age ... does not preclude 
augmentation of collateral vessel development in response to exogenous angiogenic cytokines." Whether these findings can be extrapolated to human subjects is of prime interest in this essay.

\section{NEUROANGIOGENESIS}

Again, there are little direct data on NAG factors in the brain to parallel those figures reported above for VEGF mRNA expression in ischemic muscles of older rabbits and mice. But there is a general consensus about the presumed importance of such factors in the brain. For example, in 1986 Bär et al. wrote that the maintenance or repair of cerebral capillaries in rats "needs a continuous action of an angiogenetic stimulus" [109]. In 1992, Ferrara et al. suggested that the "presence of the growth factor may be required to maintain the differentiated state of those vessels [rat cerebral capillaries], which otherwise might undergo involution" [110]. And a decade later, when writing about angiogenesis in general, Carmeliet also concluded that "threshold levels of VEGF [are needed] for the survival and maintenance of quiescent vessels in healthy organs" [111].

NAG in rats. Several research groups have determined levels of VEGF mRNA during the immediate postnatal period in rats $[112,113]$. To my knowledge, levels during later ages have not been reported in rodents, except for the study in mice (and rabbits) by Rivard et al. noted above. Nonetheless, such levels can be inferred in one notable study comparing young vs. older rats challenged under different conditions. De la Torre developed rat models of chronic hypoperfusions in which visuospatial memory impairment and recovery from were measured by the Morrison water maze test [25]. Three different age groups of rats were studied for the speed of their recovery. Young rats recovered soonest, middle age rats more slowly, and old rats not at all. My interpretation of these findings is that old rats lacked an adequate restorative or 
maintenance level of NAG factors, while middle age rats had a moderate level and younger ones possessed them in healthy abundance [93].

NAG in people. Unlike the ample data showing a declining CCD in aged person (Table 3), comparative levels of VEGF or other angiotrophic factors have not been reported in healthy mature subjects versus elderly persons. Kalaria et al. found "enhanced VEGF immunoreactivity in clusters of reactive astrocytes" in the neocortex of AD brains compared to those of elderly controls, but the authors attributed this "compensatory mechanism to counter insufficient vascularity or reduced perfusion apparent in AD" [114]. Yang et al. found that VEGF is colocalized with beta amyloid plaques of patients with AD, but they ascribed this to "vascular dysfunction in the progression of $\mathrm{AD}$ " [115]. Neither of these studies defines clearly the relative general levels of NAG factors in adults versus aged subjects.

\section{THE NAG HYPOTHESIS AND COGNITIVE RESERVE}

A troubling issue for advocates of the amyloid cascade theory has been "the imperfect correlation between cognitive status and [amyloid- $\beta$ ] deposits in the brain" [116]. Some persons cognitively normal at death exhibit abundant accumulation of amyloid plaques and neurofibrillary tangles, while others with dementias show negligible cerebral amyloid involvement [117-122]. The former group represents a dilemma for the amyloid cascade hypothesis, while the latter cases might be simply diagnosed as VaD or "pre-AD." The NAG hypothesis may explain this discrepancy based on the view that individuals may vary in their "cognitive reserve" - a term used previously by several investigators and now relevant to the NAG hypothesis, as discussed next [123-125]. 
Individuals with a putative greater neurological/cognitive reserve than others may tolerate neurological damage from amyloid other neuropathology without displaying evidence of cognitive impairment if they have a compensatory, superior microcirculation supporting that reserve. Thus "amyloid-laden" or microinfarcted subjects who are cognitively normal may have a high CCD level, adequate to support needed neurons, while "amyloid-poor" or infarct-free persons who are cognitively deficient may have a low, inadequate CCD level. In other words, if toxic amyloid deposits or some other cerebral pathology reduce neuronal and synaptic function to a borderline level, these conditions may not yet produce recognizable mental impairment in some persons who, however, could be tipped into dementia by the decline in their CCD as they age further. Again, the import of this aside is that a reduced CCD during aging may have a deleterious effect on brain function added to any primary pathology produced in the brain - e.g., by amyloid, etc. (Table 1).

\section{NEURONAL LOSS VERSUS SYNAPTIC DYSFUNCTION}

According to the NAG hypothesis, administering angiogenic factors to persons with SDs might forestall further mental deterioration. Treatment might also recover faded memories and revive lost executive functions if the defective cognition is due merely to synaptic dysfunction rather than neuronal loss. In a given person, cognitive impairment may result from either neuronal dysfunction/death, synaptic dysfunction, or both. Neuronal loss is currently believed to be generally irreversible, while synaptic connections appear to wax and wane with demand, as evidenced in the brains of some time jugglers and London taxi drivers. Neuronal loss is consistently found in subjects with AD but is an unsettled issue in papers concerning cognitively impaired aged persons having no evidence of $\mathrm{AD}[76,126,127]$. Many such studies have failed 
to find neuronal loss in the latter $[75,128]$. This suggests that cognitive decline in non-AD subjects may be due mainly to synaptic dysfunction. Thus, a beneficial outcome with NAG therapy seems more probable in memory-challenged aged persons lacking signs of AD than in persons with overt AD. However, some part of the impaired cognition in AD may also be due to reversible synaptic dysfunction.

\section{THERAPEUTIC OPTIONS FOR SDs}

Issa et al. found elevated levels of vascular endothelial growth factor (VEGF) in the penumbra of the infarcted area of human brain tissue after ischemia stroke. They proposed the factor as a potential therapeutic agent [129]. Numerous studies in rats and mice reported the positive effect of VEGF on surgically-induced focal cerebral ischemia [130-138]. The report by Rivard et al. discussed earlier is an example in rabbits and mice of enhanced muscle vascularity following VEGF treatment [108].

Using such factors to treat aged persons with $\mathrm{AD}$ has also been inferred or proposed previously by others. In 2004 Ward \& LaManna wrote, "It had been suggested that controlling angiogenesis may also provide novel therapeutic approaches for treatment of [various] disorders," such as AD, etc. [102]. Carmeliet \& Jain remarked, "The revascularization of ischaemic tissues would benefit millions, but therapeutic angiogenesis is an unmet medical need" [103]. Wang et al. observed that "little is known about the restorative effect of VEGF for AD in vivo," but based on their studies in [transgenic] mice showing improved cognitive function when injected with VEGF, the authors proposed "that VEGF should be pursued as a novel therapeutic agent for treatment of AD" [138]. This therapy would seem also applicable for all SDs. 
Evidence that angiotrophic factors may benefit persons with AD came from a complex surgical procedure for enhancing their cerebral circulation. In 1996, Harry S. Goldsmith began transposing human omentum onto the brain surface of persons with AD [139]. An omental pedicled flap was lifted from the transverse colon and passaged subcutaneously up the abdomen, chest, and neck to the base of the skull. After being pulled through openings in it, the dura mater, and arachnoid membrane, the flap was laid directly on the parietal-temporal area of one hemisphere -- all the while maintaining the original circulation [140]. Previous studies in dogs and monkeys had shown that this procedure increased the cerebral blood flow through the collateral circulation which developed between the omental pedicle and the surface of the brain.

Research groups with Goldsmith and with William R. Shankle reported in numerous papers that some AD subjects showed marked improvement mentally and physically [140-142]. This procedure had also been found to benefit patients who suffered with transient ischemic attacks or were poststroke [143].

Post mortem examination of the brains of a dozen or so such AD cases given such grafts confirmed that collateral circulation had been established in the area underneath the pedicle and also "in zones unrelated to omental placement, such as the occipital area and the contralateral cerebral hemisphere" [143]. The question arises of how other areas of the brain (e.g., hippocampus, frontal cortex) remote from the above, benefited from the omental pedicle, as reflected in the general cognitive improvement? Besides increasing the local blood flow, Goldsmith et al. speculated that the pedicle graft might also provide the brain elsewhere with angiogenic and neurotrophic factors produced by omental adipocytes [143].

Zhang et al. measured levels of VEGF protein in 19 tissues and organs of rats [144]. A few are listed here: omentum at $884 \mathrm{pg} / \mathrm{mg}$, inguinal adipose tissue at 87, pituitary at 106, brain 
at 8 , brain stem at 1.45 . They also cultured rat omental adipocytes and vascular stromal cells and found the former to be the primary source of endothelial cell mitogen. A "major portion" of this was abolished by VEGF antibody, confirming VEGF as the prominent angiogenic factor produced by the omentum. If similar high levels of VEGF occur in the human omentum, this would explain the more remote effect in the brain of omental pedicles laid on its surface and would support Goldsmith's speculation.

\section{CAUTIONS CONCERNING NAG THERAPY}

Recombinant forms of many trophic factors are now available for experimental and clinical use [145]. Recent research by Chopp et al. on strokes noted earlier suggests that several factors may be required for their optimal treatment [130]. The same consideration might also apply to a waning CCD in persons with senile dementias.

The synergistic effect of VEGF and basic FGF on angiogenesis was reported in both cultured endothelial cells and a rabbit ischemic hind limb model [146-149]. The "complementary actions of VEGF and angiopoietin-1 on blood vessel growth and leakage" have been discussed in three papers [150-152]. Zang et al. described how VEGF enhances angiogenesis but promotes blood-brain barrier leakage in the ischemic brain [134]. Recall that VEGF was originally termed vascular permeability factor. In mice, angiopoietin-1 protects the vasculature against plasma leakage [151]. The reports above justify emphasizing below the reservations expressed by others regarding therapy with NAG factors.

Carmeliet has stressed that vessel formation is a "complex process, requiring a finely tuned balance between numerous stimulating and inhibitory signals" [111]. Yancopoulos et al. wrote that several members of the VEGF, angiopoietin, and ephrin families "interact in a 
complementary and coordinated manner to form functional vessels [capillaries] without leaks." The use of a single growth factor to reconstitute a vascular bed is "now viewed as somewhat naïve and even misguided" [152]. Three other groups expressed a similar concern $[136,149,150]$. And very recently Thau-Zuchman et al. stressed that treating traumatic brain injuries with VEGF along "could be a double edged sword," for it might increase vascular permeability and exacerbate cerebral edema [153]. However, none of the animal studies using VEGF have reported unusual internal bleeding, but they were short term experiments.

\section{ROUTES OF ADMINISTRATION}

In earlier publications, I outlined various routes for introducing NAG factors into the brain $[93,94]$. The following is a distillation of that review. Parenterally administered NAG factors, as well as those given orally and absorbed into the circulation, would have access to receptors on the intraluminal surface of all capillaries in the body. These two routes have the obvious drawback in that the NAG factors would not be limited to the brain but would reach other parts of the body where they might produce undesirable angiogenesis. But blood borne NAG factors could become localized in the brain if they were first modified by either of following two methods -1 ) being conjugated to an antibody specific for an antigen on the intraluminal surface of capillary endothelial cells or 2) coupled to magnetic nanoparticles, introduced into the circulation (or CSF), and attracted to the cerebral capillary bed and maintained there by a magnetic field maintained over the skullcap.

Studies on Parkinson's disease and related neurological diseases have employed three other routes for administering drugs directly into the brain: indwelling catheters in the lateral ventricle for access to the CSF, multiple microcatheters penetrating the skull and reaching the 
subarachnoid space over the cerebral hemisphere, and burr holes in the calvaria allowing access to the surface of the cerebral cortex for placing slow sustained release systems $[93,154-156]$. Any of these three avenues could be tested experimentally on a small number of subjects with $\mathrm{AD}$, but none is practical as a "standard" method for millions of aged persons. However, the transnasal route introduces agents directly into the brain and seems an eminently suitable method for the frequent, regular delivery of NAG factors.

\section{TRANSNASAL THERAPY}

There are numerous summaries describing this delivery method [157-160]. Agents crossing the nasal epithelium may gain access to the brain by three routes: neural, lymphatic, or vascular [161]. The olfactory nerves (beneath the olfactory mucosa) offer either of two pathways $-\mathrm{a}$ intracellular/transcellular pathway (within receptor-mediated neurons) and a extracellular/paracellular pathway (via channels formed by ensheathing cells along the axons). Transport of drugs along the former is slow, while that along the latter is fast with some drugs reaching the brain within $30 \mathrm{~min}$. [158,159]. This is an optimal path for neurotrophic factors but would seem less so for neuroangiogenic ones.

A second route, the lymphatics, involves CSF in perineural and perivascular spaces leading into the subarachnoid space and thence into the brain parenchyma. Angiogenic factors presumably act on the intraluminal surface of capillaries. If these factors entered the brain's interstitial spaces by either of the above two routes, they might reach the interior of capillaries by the reverse of the usual outward passage across the BBB.

A third route involves small blood vessels in the lamina propria underlying the mucosa of the nasal vestibule, olfactory region, and respiratory region. Nasal arteries convey blood via 
local capillaries to nasal veins which join the facial veins, innominate veins, etc. to complete its return to the heart. But nasal veins also connect to the perihypophyseal vascular complex. A cavernous sinus-carotid artery complex is the counterpart in man and rats to the carotid rete mirabile in pigs, sheep, and oxen. By this short cut, venous blood from the nose may enter the arterial system of the brain in a process termed "counter current exchange" [161]. Any NAG factors present would thus reach capillaries in the brain and could possibly promote angiogenesis on their intraluminal surface.

The feasibility of transnasal therapy in people is supported by many animal studies. For example, Shipley inserted gelfoam soaked in a wheat germ agglutinin-horseradish peroxidase solution into the nose of rats and later found this marker in neurons "in the midbrain and pons throughout the entire expanse of the olfactory cortex to the caudal pole of the cerebral hemisphere" [162]. Investigators with William H. Frey II have used the transnasal route for administering various neurotrophic factors and also insulin to mice and rats [163-166]. They administered recombinant human NGF by nose drops to anesthetized rats and used an enzymelinked immunosorbent assay to localize the factor in the brain [167]. They found concentrations of NGF within an hour reached 3,400 picomoles in the olfactory bulb (lying on the cribriform plate) and 660-2200 picomoles in four "adjacent brain regions" and several subcortical regions hippocampus and amygdala.

In an early paper by this group, the authors suggested that the intranasal route be used for "long-term treatment of Alzheimer's disease" with "potent drugs, including peptides and proteins" [167]. Clinical trials in AD subjects are now underway with insulin administered transnasally [168]. For introducing NAG factors, a nasal spray would seem an obvious vehicle, but a recent article on this subject included the picture of an $18^{\text {th }}$ century English gentleman 
taking a pinch of snuff [94]. Perhaps in the future, people may regularly use nicotine-free snuff containing the appropriate cocktail of NAG factors to ward off or ameliorate senile dementias.

\section{SUMMARY \& CONCLUSIONS}

This essay is a synthesis of data and ideas culled from the enormous literature concerning AD, amyloid, SDs, aging, and other areas. In 17 published studies, data on cerebral capillaries show reduced values in older animals and people (Tables $2 \& 3$ ). Among the numerous articles on $\mathrm{AD}$ which I have read, only five examined the $\mathrm{CCD}$ in various parts of the brain (Table 3, \#16-20), but each such paper reported reduced values compared with control groups. These observations have not been accorded any general note by other investigators of AD. Nor has consideration been given to the idea that an age-linked decline in the CCD may be important in the terminal clinical course of persons with various SDs.

The NAG hypothesis presented here proposes that senile dementia, and in some instances $\mathrm{AD}$, may be caused by a reduced $\mathrm{CCD}$ due to a genetically determined, age-linked decline of NAG factors. Capillary function may compromised by various other mechanisms (e.g., amyloid deposits, microinfarcts, etc.), but the age-linked reduced CCD occurs in addition to them. The resulting decreased delivery of oxygen and glucose to the brain parenchyma would undermine neuronal and synaptic function in the aged and in AD. A reduced CCD could impair cognition independent of any other of the various pathologies proposed as causing AD and listed in Table

1. In elderly persons (with or without $\mathrm{AD}$ ), a waning $\mathrm{CCD}$ may be a terminal vascular condition, accounting for impaired cognition. The concept of cognitive reserve is a key consideration in the NAG hypothesis. 
An age-linked decline of NAG factors renders SDs a deficiency disorder, theoretically amenable to replacement therapy. The administration of recombinant neuroangiogenic factors has been shown to augment capillary density following surgically induced focal cerebral ischemia in rats and hind limb ischemia in rabbits. The NAG hypothesis offers a rational basis for considering these factors in the treatment of persons with SDs. The most practical route for administering a safe, suitable cocktail of angiongenic factors over many years may be an intranasal one, as in a nasal spray or perhaps via a snuff-like preparation.

Finally, as indicated earlier, the NAG hypothesis is not a rival to other theories concerning the etiopathology of AD, which indeed may have multiple ones. Hickham's dictum states that "Patients can have as many diseases as they damn well please" [169]. By analogy, some disease conditions like AD may have multiple causes. Indeed, certain cases of $\mathrm{AD}$ might possibly benefit from dual treatment - for the diminished capillary circulation and for some other underlying cerebral pathology. 


\section{ACKNOWLEDGEMENTS}

I am very grateful for the valuable, insightful comments made by three reviewers of early versions of this paper. I am again indebted to the Medical Center Library of the University of Kentucky and in particular to its very helpful staff member, Mrs. Amanda Williams. Finally I acknowledge the support of I.S. Tray II.

\section{FOOTNOTES:}

[1] The Indian elephant pictured in Table 1 refers to the legend of the six blind Hindus who encountered one for the first time. Each described it according to the particular part of its body he examined. The legend parallels somewhat research on AD.

\section{REFERENCES}

[1] de la Torre JC (2011) Three postulates to help identify the cause of Alzheimer's disease. $J$ Alzheimer Dis 24, 657-66.

[2] Hardy JA, Higgins GA (1992) Alzheimer's disease: the amyloid cascade hypothesis. Science 256, 184-185.

[3] Hardy J, Selkoe DJ (2002) The amyloid hypothesis of Alzheimer's disease: progress and problems on the road to therapeutics. Science 297, 353-356.

[4] Selkoe DJ (2013) Snapshot: Pathobiology of Alzheimer's disease. Cell 15 468.e1. 
[5] Grammas P (2011) Neurovascular dysfunction, inflammation and endothelial activation: Implications for the pathogenesis of Alzheimer's disease. J Neuroinflammation 8, 1-12.

[6] Thies W, Bleiler L (2011) Alzheimer's Association Report: 2011 Alzheimer's disease facts and figures. Alzheimer's \& Dementia 7, 208-244.

[7] Iadecola C (2004) Neurovascular regulation in the normal brain and in Alzheimer's disease. Nature Reviews Neuroscience 5, 347-360.

[8] Gold G, Giannakopoulos P, Bouras C (1998) Reevaluating the role of vascular changes in the differential diagnosis of Alzheimer's disease and vascular dementia. Eur Neurol 40, 121129.

[9] Shi J, Perry G, Smith MA, Friedland RP (2000) Vascular abnormalities; the insidious pathogenesis of Alzheimer's disease. Neurobiology Aging 21: 357-361.

[10] Roher AE, Esh C, Rahman A, Kokjohn TA, Beach, TG (2004) Atherosclerosis of cerebral arteries in Alzheimer disease. Stroke 35, 2623-2627.

[11] Yamada, M, Ihara M, Okamoto Y, Maki T, Washida K, Kitamura A, Hase Y, Hiddefumi I, Takao Km Miyakawa T, Kalaria RN, Tomimoto H, Takahashi R (2011) The influence of chronic cerebral hypoperfusion on cognitive function and amyloid B metabolism in APP overexpressing mice. PLoS One 6(1), e16567.

[12] Scheibel AB (1984) Changes in brain capillary structure in aging and dementia. in Wertheimer J, Marois M. (eds.). Senile Dementia Outlook for the Future. New York: Alan R. Liss, pp. 137-149.

[13] Kety SS (1950) Circulation and metabolism of the human brain in health and disease. Am $J$ Med 8 205-217. 
[14] Obrist WD, Chivian E, Cronqvist S, Ingvar DH (1970) Regional cerebral blood flow in senile and presenile dementia. Neurology 20, 315-322.

[15] Hagberg B (1978) Defects of immediate memory related to the cerebral blood flow distribution. Brain Language 5, 366-377.

[16] Melamed E, Lavy S, Bentin S, Cooper G, Rinot Y (1980) Reduction in regional cerebral blood flow during normal aging in man. Stroke 11, 31-35.

[17] Shaw TG, Mortel KF, Meyer JS, Rogers RL, Hardenberg J, Cutaia MM (1984) Cerebral blood flow changes in benign aging and cerebrovascular disease. Neurology 34, 855-862. [18] Montaldi D, Brooks DN, McColl JH, Wyper D, Patterson J, Barron E, McCulloch J (1990) Measurements of regional cerebral blood flow and cognitive performance in Alzheimer's disease. J Neurology Neurosurg Psych 199053, 33-38.

[19] Eberling JL, Jagust WJ, Reed BR, Baker MG (1992) Reduced temporal lobe blood flow in Alzheimer's disease. Neurobiology Aging 13, 483-491.

[20] Wademar G, Bruhn P, Kristensen M, Johnsen A, Paulson OB (1994) Heterogeneity of neocortical cerebral blood flow deficits in dementia of the Alzheimer type: a $\left[{ }^{99 \mathrm{~m}} \mathrm{Tc}\right]-d, l-$ HMPAO SPECT study. J Neurol Neurosurg Psychiatry 57, 285-295.

[21] Ajmani RS, Metter EJ, Jaykumar R, Ingram DK, Spangler El, Abugo OO, Rifkind JM (2000) Hemodynamic changes during aging associated with cerebral blood flow and impaired cognitive function. Neurobiology Aging 21, 257-269.

[22] Kalaria RJ (2000) Blood brain barrier dysfunction and cerebrovascular degeneration in Alzheimer's disease. Chapt 11 in Verbeck MM, de Waal RMW, Vinters HV (eds.) Cerebral Amyloid Angiopathy in Alzheimer's Disease and Related Disorders. London: Kluweer Academic Publ, pp. 189-206. 
[23] Goldman H, Berman RF, Gershon S, Murphy SL, Altman HJ (1987) Correlation of behavioral and cerebrovascular functions in the aging rat. Neurobiology Aging 8, 409-416. [24] Cada A, de la Torre JC, Gonzalez-Lima F (2000) Chronic cerebrovascular ischemia in aged rats; effects on brain metabolic capacity and behavior. Neurobiology Aging 21, 225-233. [25] de la Torre JC (1997) Hemodynamic consequences of deformed microvessels in the brain in Alzheimer’s Disease. Ann NY Acad Sci 826, 75-91.

[26] de la Torre JC (2002) Alzheimer disease as a vascular disorder. Nosological evidence. Stroke 33, 1152-1162.

[27] de la Torre JC (2004) Is Alzheimer's disease a neurodegenerative or a vascular disorder? Data, dogma, and dialectives. The Lancet Neurology 3, 184-190.

[28] Mancardi GL, Perdelli F, Rivano C, Leonardi A, Bugiani O (1980) Thickening of the basement membrane of cortical capillaries in Alzheimer's disease. Acta Neuropath 49, 79-813. [29] Hardy JA, Mann DMA, Wester P., Winblad B (1986) An integrative hypothesis concerning the pathogenesis and progression of Alzheimer's disease. Neurobiol Aging 7, 489502.

[30] Perlmutter LS, Chui HC (1990) Microangiopathy, the vascular basement membrane and Alzheimer's disease: a review. Brain Res Bull 24, 677-686.

[31] de la Torre JC (1994) Impaired brain microcirculation may trigger Alzheimer's disease. Neurosci Biobehavioral Rev 18, 397-401.

[32] Zhang ZG, Zhang L, Jiang Q, Zhang R, Davies K, Powers C, Bruggen N, Chopp M (2000) VEGF enhances angiogenesis and promotes blood-brain barrier leakage in the ischemic brain. $J$ Clin Invest 106, 829-838. 
[33] Alvarez JI, Dodelet-Devillers A, Kebir H, Ifergan I, Fabre PJ, Terouz S, Sabbagh M, Wosik K, Bourbonnière L, Bernard M, van Horssen J, de Vries HE, Charron F, Prat A (2011) The hedgehog pathway promotes blood-brain barrier integrity and CNS immune quiescence. Science 334, 1727-1731.

[34] Biron KE, Dickstein DL, Gopaul R, Jefferies WA (2011) Amyloid triggers extensive cerebral angiogenesis causing blood brain barrier permeability and hypervascularity in Alzheimer's Disease. PLoS ONE 6, 1-10.

[35] de la Torre JC, Mussivand T (1993) Can disturbed brain microcirculation cause Alzheimer's disease? Neurol Res 15, 146-153.

[36] Kalaria RN (1996) Cerebral vessels in ageing and Alzheimer's disease. Pharmacol Ther 72, 193-214.

[37] Zlokovic BV (2008) The blood-brain barrier in health and chronic neurodegenerative disorders. Neuron 57, 178-201.

[38] Hachinski VC, Lassen NA, Marshall J (1974) Multi-infarct dementia; a cause of mental deterioration in the elderly. The Lancet 2: 207-210.

[39] Kalaria RN (2012) Cerebrovascular diseases and mechanisms of cognitive impairment. Stroke 43: 2526-2534.

[40] Smith EE, Wardlaw JM, Greenberg SM (2012) Cerebral microinfarcts: the invisible lesions. Neurology 11: 271-281.

[41] Brundel M, de Bresser J, van Dillen JJ, Kappelle LJ, Biessels GJ (20102) Cerebral microinfarcts: a systemic review of neuropatholoigcal studies. J. Cerebral Blood Flow Metabolism 32: 425-436. 
[42 ] Cullen KM, Kósci Z, Stone J. (2006) Microvascular pathology in the aging human brain: Evidence that senile plaques are sites of microhemorrhages. Neurobiology Aging 27: 1786-1796. [43] Tuke JB (1873) On the morbid histology of the brain and spinal cord as observed in the insane. Brit Foreign Med-Chirur Rev 51, 450-460.

[44] Hassler O (1967) Arterial deformities in senile brains. Acta Neuropathol 8, 219-229.[45] Wilkinson JH, Hopewell JW, Reinhold HS (1981) A quantitative study of age related changes in the vascular architecture of the rat cerebral cortex. Neuropathol Appl Neurobiol 7, 451-462. [46] Ravens JR (1978) Vascular changes in the human senile brain. Adv Neurology 20, 487502.

[47] Fisher VW, Siddiqi A, Yusufaly Y (1990) Altered angioarchitecture in selected areas of brains with Alzheimer's disease. Acta Neuropath 79, 672-679.

[48] Bailey TL, Rivara CB, Rocher AB, Hof PR (2004) The nature and effects of cortical microvascular pathology in aging and Alzheimer's disease. Neurol Res 26, 573-578. [49] Craigie EH (1925) Postnatal changes in vascularity in the cerebral cortex of the male albino rat. J Comp Neurol 39, 301-324.

[50] Terry RD, Peck A, DeTeresa R, Schechter, RF, Horoupian DS (1981) Some morphometric aspects of the brain in senile dementia of the Alzheimer type. Ann Neurol 10, 184-192.

[51] West MJ (1993) New stereological methods for counting neurons. Neurobiol Aging 14, 275-283.

[52] Gomez-Isla T, Hollister R, West H, Mui S, Growdon JH, Petersen RD, Parisi JE, Hyman BT (1997) Neuronal loss correlates with but exceeds neurofibrillary tangles in Alzheimer's disease. Ann Neurol 41, 17-24. 
[53] Amenta F, Ferrante F, Mancini M, Sabbatini M, Vega JA, Zaccheo D (1995a) Effect of long term treatment with the dihydropyridine-type calcium channel blocker darodipine (PY 108068) on the cerebral capillary network in aged rats. Mechan Ageing Devel 78, 27-37.

[54] Klein AW, Michel ME (1977) A morphometric study of the neocortex of young adult and old maze-differentiated rats. Mechanisms Ageing Develop 6, 441-452.

[55] Knox CA, Oliveira A (1980) Brain aging in normotensive and hypertensive strains of rats. Acta Neurpathol (Berl) 52, 17-25.

[56] Knox CA (1982) Effect of aging and chronic arterial hypertension on the cell population in the neotortex and archicortex of the rat. Acta Neuropath (Berl) 56, 139-145

[57] Casey MA, Feldman ML (1985) Aging in the rat medial nucleus of the Trapezoid body. III Alterations in capillaries. Neurobiol Aging 6, 39-46.

[58] Buchweitz-Milton E, Weiss HR (1987) Perfused capillary morphometry in the senescent brain. Neurobiology Aging 8, 271-276.

[59] Junker M, Meier-Ruge W. (1989) Effects of brovincamine on stereological capillary parameters in adult and old Fischer-344 rats. Microvasc Res 37, 298-307.

[60] Junker M, Bättig K, Meier-Ruge W (1990) Effects of aging and vincamine derivatives on pericapillary microenvironment: stereological characterization of the cerebral capillary network. Neurobiology Aging 11, 39-46.

[61] Amenta F, Cavallotti D, Del Valle M, Mancini M, Naves FJ, Vega JA, Zeng Y-C (1995b) Age-related changes in brain microanatomy: Sensitivity to treatment with the dehydropyridine calcium channel blocker darodipine (PY 108-068). Brain Res Bull 36, 453-460. 
[62] Burns EM, Kruckeberg MS, Comerford BWS, Buschmann MBT (1979) Thinning of capillary walls and declining numbers of endothelial mitochondria in the cerebral cortex of the aging primate Macaca nemestrina. J Gerontology 34, 642-650.

[63] Burns EM, Kruckeberg TW, Gaetano PK (1981) Changes with age in cerebral capillary morphology. Neurobiology Aging 2, 285-291.

[64] Mann DM, Eaves NR, Marcyniuk B, Yates PO (1986) Quantitative changes in cerebral cortical microvasculature in ageing and dementia. Neurobiol Ageing 7, 321-330.

[65] Abernathy WB, Bell MA, Morris M, Moody DM (1993) Microvascular density of the human paraventricular nucleus decreases with aging but not hypertension. Expl Neurobiology $121,270-274$.

[66] Bell MA, Ball MJ (1981) Morphometric comparison of hippocampal microvasculature in ageing and demented people: diameters and densities. Acta Neuropathol (Berl) 53, 299-318. [67] Bell MA, Ball MJ (1990) Neuritic plaques and vessels of visual cortex in aging and Alzheimer's dementia. Neurobiology Aging 11, 359-370.

[68] Buée L, Hof PR, Bouras C, Delacourte A, Perl DP, Morrison JH, Fillit HM (1994) Pathological alterations of the cerebral microvasculature in Alzheimer's disease and related dementing

[69] Kitaguchi H, Ihara M, Saiki H, Takahashi R, Tomimoto H (2007) Capillary beds are decreased in Alzheimer's disease but not in Binswanger's disease. Neuroscience Letters 417, 128-131.

[70] Kuwabara T, Cogan DG (1963) Retinal vascular patterns. Arch Ophth 69, 492-502. [71] Hunziker O, Abdel-Al S, Schulz U (1979) The aging human cerebral cortex: a stereological characterization of changes in the capillary net. J Gerontology 34, 345-350. 
[72] Meier-Rouge W, Schulz-Dazzi U (1989) Effects of bromovincamine on the stereological parameters of corticocerebral capillaries. Life Sci 40, 943-949.

[73] Black JE, Pollinsky M, Greenough WT (1989) Progressive failure of cerebral angiogenesis supporting neural plasticity in aging rats. Neurobiol Aging 10, 353-358.

[74] Henderson G, Tomlinson BE, Gibson PH (1980) Cell Counts in human cerebral cortex in normal adults throughout life using an image analyzing computer. J Neurolog Sci 46, 113-136. [75] Haug H (1984) Macroscopic and microscopic morphometry of the human brain and cortex. A survey in the light of new results. Brain Path 1, 123-149.

[76] Coleman PD, Flood DG (1987) Neuron numbers and dendritic extent in normal aging and Alzheimer's disease. Neurobiol Aging 8, 521-545.

[77] Davies CA, Mann DMA, Sumpter PQ, Yates PO (1987) A quantitative morphometric analysis of the neuronal and synaptic content of the frontal and temporal cortex in patients with Alzheimer's disease. J Neurolog Sci 78, 151-164.

[78] Smith CG (1934) The volume of the neocortex of the albino rat and the changes it undergoes with age after birth. J Comp Neurol 60, 319-347.

[79] Bartzokis G, Beckson M, Lu PH, Nuechterlien KH, Edwards N, Mintz J (2001) Agerelated changes in frontal and temporal lobe volumes in men. Arch Gen Psychiatry 58, 461-465. [80] Salat D, Kaye JA, Janowsky JS (2001) Selective preservation and degeneration within the prefrontal cortex in aging and Alzheimer disease 58, 1403-1408.

[81] Tisserand DJ, Pruessner JC, Arigita EJS, van Boxtel MPJ, Evans AC, Jolles J, Uylings HBM (2002) Regional frontal cortical volumes decrease differentially in aging: an MRI study to compare volumetric approaches and voxel-based morphometry. Neuroimage 17, 657-669. 
[82] Walhovd KB, Fjell AM, Reinvang I, Lundervold A, Dale AM, Eilertsen DE, Quinn BT, Salat D, Makris N, Fischl B (2005) Effects of age on volumes of cortex, white matter and subcortical structures. Neurobiol Aging 26, 1261-1270.

[83] Appel FW, Appel EM (1942) Intracranial variation in the weight of the human brain (concluded). Human Biol 14, 235-250.

[84] Smith CG (1934) The volume of the neocortex of the Albino rat and the changes it undergoes with age after birth. J Comp Neurol 60, 319-347.

[85] Jernigan TL, Archibald SL, Fennema-Notestine C, Gamst AC, Stout JC, Bonner J, Hesselink JR (2001) Effects of age on tissues and regions of the cerebrum and cerebellum. Neurobiol Aging 22, 581-594.

[86] Mu Q, Xie J, Wen Z, Weng Y, Shuyun Z (1999) A quantitative MR study of the hippocampal formation, the amygdala, and the temporal horn of the lateral ventricle in healthy subjects 40 to 90 years of age. AJKNR Am J. Neuroradiol 20, 207-211.

[87] Pantel J, Kratz B, Essig M, Schröder J (2003) Parahippocampal volume deficits in subjects with aging-associated cognitive decline. Am J Psychiatry 160, 379-382.

[88] Walhvod KR, Westlye LT, Amlien I, Espeseth T, Reinvang I, Raz N, Agartz I, Salat DH, Greve DN, Fischl B, Dale AM, Fjell AM (2011) Consistent neuroanatomical age-related volume differences across multiple samples. Neurobiol Aging 32, 916-932.

[89] Ambrose CT (2010) The Widening Gyrus. American Scientist 98, 270-274.

[90 ] Elbert T, Pantev CV, Wienbruch C, Rockstroh B, Taub E (1995) Increased cortical representation of the fingers of the left hand in string players. Science 270: 305-307.

[91] Draganski B, Gaser C, Busch V, Schuierer G, et al. (2004) Changes in grey matter induced by training. Nature 427, 311-312. 
[92] Woollet K, Spiers HJ, Maguire EA (2009) Talent in the taxi: a model system for exploring expertise. Phil Trans R Soc B 364, 1407-1416.

[93] Ambrose CT (2012) Neuroangiogenesis: a vascular basis for Alzheimer's disease and cognitive decline during aging. J Alzheimer Dis 32, 773-788.

[94] Ambrose CT (2013) Alzheimer's disease: the Great Morbidity of the $21^{\text {st }}$ century. Am Sci 101, 194-201.

[95] Roth M (1955) The Natural history of mental disorder in old age. J Mental Sci 101, 281301.

[96] Brun A, Gustafson L (1976) Distribution of cerebral degeneration in Alzheimer's disease. A Clnico-Pathological Study. Arch Psychiat Nervenkr 223, 15-33.

[97] Dickson DW (2001) Neuropathology of Alzheimer's disease and other dementias. Clinics Geriatric Med 17, 209-228.

[98] Klagsbrun M, D’Amore PA (1991) Regulators of angiogenesis. Ann Rev Physiol 53, 217239.

[99] Yancopoulos GD, Davis S, Gate NW, Rudge JS, Wiegand SJ, Holash J (2000) Vascularspecific growth factors and blood vessel formation. Nature 407, 242-248.

[100] Felmeden DC, Blann AD, Lip GYH (2003) Angiogenesis: basic pathophysiology and implications for disease. European Heart J 24, 586-603.

[101] Zadeh G, Guha A (2003) Angiogenesis in nervous system disorders. Neurosurgery 53, 1362-1376.

[102] Ward NL, LaManna JC (2004) The neurovascular unit and its growth factors: coordinated response in the vascular and nervous systems. Neurological Res 26, 870-883. 
[103] Carmeliet P, Jain RK (2011) Molecular mechanisms and clinical applications of angiogenesis. Nature 473, 298-307.

[104] Ferrara N, Gerber H-P, LeCouter J (2003) The biology of VEGF and its receptors. Nature Medicine 9, 669-676

[105] Felmeden DC, Blann AD, Lip GYH (2003) Angiogenesis: basic pathophysiology and implications for disease. Europ Heart J 24: 586-603.

[106] Krupinski J, Kaluza J, Kumar P, Kumar S, Wang JM (1994) Role of angiogenesis in patients with cerebral ischemic stroke. Stroke 25, 1794-1798.

[107] Carmeliet P, Jain RK (2011) Molecular mechanisms and clinical applications of angiogenesis. Nature 473, 298-307.

[108] Rivard A, Fabre J-E, Silver M, Chen D, Murohara T, Kearney M, Magner M, Asahar T, Isner JM (1999) Age-dependent impairment of angiogenesis. Circulation 99, 111-120.

[109] Bär T (1986) Postnatal development of the vascular pattern in the rat telencephalic piaarachnoid. Anat Embryol 174, 215-223.

[110] Ferrara N, Houck K, Jakeman L, Leung DW (1992) Molecular and biological properties of the vascular endothelial growth factor family of proteins. Endocrine Rev 13, 18-32.

[111] Carmeliet P (2005) Angiongenesis in life, disease and medicine. Nature 438, 932-936.

[112] Breier G, Albrecht U, Sterrer S, Risau W (1992) Expression of vascular endothelial growth factor during embryonic angiogenesis and endothelial cell differentiation. Development $114,521-532$.

[113] Ment LR, Stewart WB, Fronc F, Seashore C, Mahooti S, Scaramuzzino D, Madri JA (1997) Vascular endothelial growth factor mediates reactive angiogenesis in postnatal developing brain. Develop Brain Res 100, 52-61. 
[114] Kalaria RN, Cohen DL, Premkumar DRD, Nag S, LaManna JC, Lust WD (1998)

Vascular endothelial growth factor in Alzheimer's disease and experimental cerebral ischemia. Mol Brain Res 62, 101-105.

[115] Yang S-P, Bae D-G, Kang HJ, Gwag BJ, Gho YS, Chae C-B (2004) Co-accumulation of vascular endothelial growth factor with $\boldsymbol{\beta}$-amyloid in the brain of patients with Alzheimer's disease. Neurobiol Aging 25, 283-290.

[116] Golde, TE, Schneider LS, Koo EH (2011) Anti-A $\beta$ therapeutics in Alzheimer's disease: the need for a paradigm shift. Neuron Perspective 69, 203-212. [117] Hulette CM, Welsh-Bohmer KA, Murray MG, Saunders AM, Mash DC, McIntyre LM (1998) Neuropathological and neuropsychological changes in "normal" aging: evidence for preclinical Alzheimer disease in cognitively normal individuals. J Neuropath Expl Neurology 57, 1168-1174.

[118] Lue L-F, Kuo Y-M, Roher AE, Brachova L, Shen Y, Sue L, Beach T, Kurth JH, Rydel RE, Rogers J (1999) Soluble amyloid $\beta$ peptide concentration as a predictor of synaptic change in Alzheimer's disease. Am J Path 155, 853-862.

[119] Näslund J, Haroutunian V, Mohs R, Davis KL, Davies P, Greengard P, Buxbaum JD (2000) Correlation Between Elevated Levels of Amyloid $\beta$-Peptide in the Brain and Cognitive Decline. JAMA 283, 1571-1577.

[120] Morris JC, Price JL (2001) Pathologic correlates of nondemented aging, mild cognitive impairment, and early-stage Alzheimer's disease. J Molecular Neurosci 17, 101-118. 
[121] Giannakopoulos P, Herrmann FR, Bussère T, Bouras C, Kövari E, Perl DP, Morrison JH, Gold G, Hof PR (2003) Tangle and neuron numbers, but not amyloid load, predict cognitive status in Alzheimer's disease. Neurology 60, 1495-1500.

[122] Bennett DA (2006) Postmortem indices linking risk factors to cognition. Alzheimer Dis Assoc Disord 20, S63-S68.

[123] Stern Y, Gurland B, Tatermichi TK, Tang MX, Wilder D, Mayeux R (1994) Influence of education and occupation on the incidence of Alzheimer's disease. JAMA 271, 1004-1010.

[124] Allen JS, Bruss J, Damasio H (2005) The aging brain: the cognitive reserve hypothesis and hominid evolution. Am J Human Biology 17, 673-689.

[125] Holtzman DM, Morris JC, Goate AM (2011) Alzheimer's disease: the challenge of the second century. Science Translational Med 3, 1-15.

[126] Brun A, Englund E. Regional pattern of degeneration in Alzheimer's disease: neuronal loss and histopathological grading. Histopathology 1981; 5: 549-564.

[127] Gomez-Isla T, Price JL, McKeel Jr DW, Morris JC, Growdon JH, Hyman BT (1996)

Profound loss of layer II entorhinal cortex neurons occurs in very mild Alzheimer's disease. $J$ Neurosci 16, 4491-4500.

[128] Terry RD, DeTeresa R, Hansen LA. Neocortical cell counts in normal human adult aging. Ann Neurol 1987; 21: 530—539.

[129] Issa R, Krupinski J, Bujny T, Kumar S, Kaluza J, Kumar P (1999) Vascular endothelial factor and its receptor, KDR, in human brain tissue after ischemia stroke. Lab Invest 199; 79: 417-425.

[130] Chopp M, Zhang ZG, Jiang Q (2007) Neurogenesis, angiogenesis, and MRI indices of functional recovery from stroke. Stroke 381 (part 2), 827-831. 
[131] Kovács Z, Ikezaki K, Samoto K, Inamura T, Fukui M (1996) VEGF and flt. Expression time kinetics in rat brain infarct. Stroke 271, 1865-1873.

[132] Hayashi T, Abe K, Itoyama Y (1998) Reduction of ischemia damage by application of vascular endothelial growth factor in rat brain after transient ischemia. J Cerebral Blood Flow Metab 181, 887-895.

[133] Bruggen N van, Thibodeaux H, Palmer JT, Lee WP, Fu L, Cairns B, Tumas D, Gerlai R, Williams S-P, Campagne M van L, Ferrara (1999) VEGF antagonism reduces edema formation and tissue damage after ischemia/reperfusion injury in the mouse brain. J Clin lnvest 104, 16131620.

[134] Zhang ZG, Zhang L, Jiang Q, Zhang R, Davies K, Powers C, Bruggen N, Chopp M (2000) VEGF enhances angiogenesis and promotes blood-brain barrier leakage in the ischemic brain. J Clin Invest 106, 829-838.

[135] Sun Y, Jin K, Xie L, Childs J, Mao XO, Loginova A, Greenberg DA (2003) VEGFinduced neuroprotection, neurogenesis, and angiogenesis after focal cerebral ischemia. J Clin Invest $111,1843-1851$.

[136] Manoonkitiwongsa PS, Schultz RL, McCreery DB, Whitter EF, Lyden PD (2004) Neuroprotection of ischemic brain by vascular endothelial growth factor is critically dependent on proper dosage and may be compromised by angiogenesis. J Cerebral Blood Flow 24, 693702.

[137] Kaya D, Gürsoy-Özdemir Y, Yemisci M, Tuncer N, Aktan S, Dalkara T (2005) VEGF protect brain against focal ischemia without increasing blood-brain permeability when administered intracerebroventricularly. J Cerebral Blood Flow Metab 25, 1111-1118. 
[138] Wang Y, Galvan V, Gorostiza O, Ataie M, Jim K, Greenberg DA (2006) Vascular endothelial growth factor improves recovery of sensorimotor and cognitive deficits after focal cerebral ischemia in the rat. Brain Res 1115: 186-193.

[139] Goldsmith HS (1996) Omental transposition for Alzheimer's disease. Neurological Res 181, 103-108.

[140] Goldsmith HS (2002) Treatment of Alzheimer's disease by transposition of the omentum. Ann NY Acad Sci 977, 454-467.

[141] Goldsmith HS (2011) A new approach to the treatment of Alzheimer's siseases: the need for a controlled study. J Alzheimer's Dis 25, 209-212.

[142] Shankle WR, Hara J, Bjornsen L, Gade GF, Leport PC, Ali MB, Kim J, Raimo M, Reyes L, Amen D, Rudy L, O’Heany T (2008) Omentum transposition surgery for patients with Alzheimer's disease: a case series. Neurological Res 30, 313-325.

[143] Goldsmith HS, Bacciu P, Cossu M, Pau A, Rodriguez G, Rosadini G, Ruju P, Viale ES, Turtas SW, Viale GL (1990) Regional cerebral blood flow After omental transposition to the ischaemic brain in man. A five year follow-up study. Acta Neurochirugica 106, 145-152. [144] Zhang Q-X, Magovern CJ, Mazck CA, Budenbender KT, Ko W, Rosengart TK (1997) Vascular endothelial growth factor in omentum: mechanism of the omentum-mediated angiogenesis. J Surg Res 67, 147-154.

[145] Cell Sciences, Inc., Canton, MA. See Info@ cellscience.com and other sources. [146] Goto F, Goto K, Weindel K, Folkman JK (1993) Synergistic effects of vascular endothelial growth factor and basic fibroblast growth factor on the proliferation and cord formation of bovine capillary endothelial cells within collagen gels. Lab Invest 69, 508-517. 
[147] Asahara T, Bauters C, Zheng LP, Takeshita S, Bunting S, Ferrara N, Symes JF, Isner JM

(1995) Synergistic effect of vascular endothelial growth factor and basic fibroblast growth factor on angiogenesis in vivo. Circulation 92, II-365 - II-371.

[148] Acker T, Beck H, Plate KH (2001) Cell type specific expression of vascular endothelial growth factor and angiopoietin-1 and -2 suggests an important role of astrocytes in cerebellar vascularization. Mechan Develop 108, 45-57.

[149] Thurston G (2002) Complementary actions of VEGF and angiopoietin-1 on blood vessel growth and leakage. J Anat 200, 575-580.

[150] Visconti RP (2002) Orchestration of angiogenesis and arteriovenous contributions by angiopoietins and vascular endothelial growth factor (VEGF). Proc Na Aca Sci 99, 8219-8224. [151] Thurston G, Rudge JS, Ioffe E, Zhou H, Ross L, Croll SD, Glazer N, Holash J, McDonald DM, Yancopoulos GD (2000) Angiopoietin-1 protects the adult vasculature against plasma leakage. Nature Medicine 6, 460-463.

[152] Yancopoulos GD, Davis S, Gale NW, Rudge JS, Wiegand SJ, Holash J (2000) Vascularspecific growth factors and blood vessel formation. Nature 407, 242-248.

[153] Thau-Zuchman O, Shohami E, Alexandrovich AG, Leker RR (2010) Vascular endothelial growth factor increases neurogenesis after traumatic brain injury. J Cerebral Blood Flow Metab 30, 1008-1016.

[154] Friden PM, Walus LR, Musso GF, Taylor MA, Malfoy B, Starzyk R (1991) Antitransferrin receptor antibody and antibody-drug conjugates cross the blood-brain barrier. Proc Natl Acad Sci USA 88, 4771-4775. 
[155] Ai Y, Markesbery W, Zhang Z, Grondin R,et al. (2003) Intraputamenal infusion of GDNF in aged rhesus monkeys: distribution and dopaminergic effects. J Comp Neurology 461, $250-261$.

[156] Tyler B, Wadsworth S, Recinos V, Mehta V, Vellimana A, Li K, Rosenblatt J, Do H, Gallila GL, Silu I-M, Wicks RT, Rukdek MA, Zhao M, Brem H (2011) Local delivery of rapamycin: a toxicity and efficacy study in an experimental malignant glioma model in rats. Neuro-Oncology 13, 700-709.

[157] Thorne RG, Frey II WH (2001) Delivery of neurotrophic factors to the central nervous system. Pharmacokinetic considerations. Clin Pharmacokinet 40, 907-946.

[158] Dhuria SV, Hanson LR, Frey II WH (2010) Intranasal delivery to the central nervous system: mechanisms and experimental considerations. J Pharm Sci 99, 1654-1673. [159] Malerba F, Paoletti F, Capsoni S, Cattaneo A (2011) Intranasal delivery of therapeutic proteins for neurological diseases. Expert Opin Drug Deliv 8, 1277-1296.

[160] Sood S, Jain K, Gowthamarajan K (2014) Intranasal therapeutic strategies for management of Alzheimer's disease. J Drug Targeting. Early Online : 1-16.

[161] Einer-Jensen N, Larsen L (2000) Transfer of tritiated water, tyrosine, and propanol from the nasal cavity to cranial arterial blood in rats. Exp Brain Res 1230: 216-220.

[162] Shipley MT (1985) Transport of molecules from nose to brain: transneural anterograde and retrograde labeling in the rat olfactory system by wheat germ agglutinin-horseradish peroxidase applied to the nasal epithelium. Brain Res Bull 15, 129-142.

[163] Frey II WH, Liu J, Chen X, Thorne RG, Fawcett JR, Ala TA, Rahman Y-E (1997) Delivery of $1^{25}$ I-NGF to the brain via the olfactory route. Drug Delivery $14,87-92$. 
[164] Thorne RG, Pronk GJ, Padmanabhan V, Frey II WH (2004) Delivery of insulin-like growth factor- 1 to the rat brain and spinal cord along olfactory and trigeminal pathways following intranasal administration. Neuroscience 127, 481-496.

[165] Ma M, Ma Y, Xueming Y, Guo R, Zhu W, Fan X, Xu G, Frey II WH, Liu X (2008) Intranasal delivery of transforming growth factor-betal in mice after stroke reduces infarct volume and increases neurogenesis in subventricular zone. BMC Neuroscience 9, 117-128. [166] Reger MA, Frey II WH, Baker LD, Cholerton B, Keeling ML, Belongia DA, Fishel MA, Plymate SR, Schellenberg GD, Cherrier MM, Craft S (2006) Effects of intranasal insulin on cognition in memory-impaired older adults: Modulation by APOE genotype. Neurobiology Aging 27, 451-458.

[167] Chen X-Q, Fawcett JR, Rahman Y-E, Ala TA, Frey II WH (1998) Delivery of nerve growth factor to the brain via the olfactory pathway. J Alzheimer's Dis 1, 35-44.

[168] Craft S, Baker LD, Montine TJ, Minoshima S, Watson GS, Claxton A, Arbuckle M, Callaghan M, Tsai E, Plymate SR, Green PS, Leverenz J, Cross D, Gerton B (2012) Intranasal insulin therapy for Alzheimer disease and amnestic mild cognitive impairment. Arch Neurol 69, 29-38.

[169] Trobe JD (2002) Noble J. David, MD, Reminisces. J Neuro-Ophthalmol 22: 240-246. 
Table 1. Approaches pursued in the study of Alzheimer's Disease [1, Footnote 1]

1. Nerve growth factor.

*2. Neurotoxic trace elements: $\mathrm{Al}, \mathrm{Hg}, \mathrm{Fe}, \mathrm{Cu}$

*3. Neurotransmitter deficits: cholinergic, noradrenergic, etc.

*4. Oxidative stress, oxygen free radicals,

*5. Inflammation

6. Mitochondrial dysfunction

7. Autophagy, protein turnover

*8. Neuronal cell cycle abnormalities

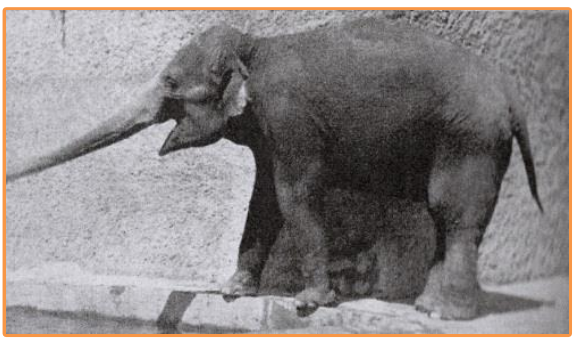

9. Calcium channel blockers

10. Cortical glucose utilization and transport across the blood brain barrier

11. Autoimmunity

12. Transmissible agent: prion, subviral entities, HSV type 1

*13. Amyloid hypothesis: A $\beta$ accumulation, BFT, amyloid aggregates, tau

14. Genetics

*15. Vascular risk factors

16. Microinfarcts in the brain

* De la Torre's seven "more cited hypothetical proposals" [1]. 
[Footnote 1] The Indian elephant pictured in Table 1 refers to the legend of the six blind Hindus who encountered one for the first time. Each described it according to the particular part of its body he examined. The legend parallels somewhat research on AD. 
TABLE 2. Cerebral capillary density in Rats, Mice, \& Macaque monkeys

$\underline{\text { Author/s }} \quad \underline{\text { Young }} \quad \underline{\text { Adult }} \quad \underline{\text { Aged }}$

RATS

1. Craigie, 1925 [49]... TABLE 7

-- sum of capil. lengths; av. of 5 laminae

$\begin{array}{ccc}\mathrm{d} 0 & 5 \mathrm{mo} & 13 \mathrm{mo} \\ 262 \mu & 856 \mu & 638 \mu \\ 231 \mu & 958 \mu & 880 \mu\end{array}$

-- regio insularis:

$231 \mu$

$880 \mu$

2. Klein \& Michel, 1977 [54]... Table III

-- number of vascular elements/Chalkley count

-- frontal \& occiptal neocortex: $\quad$-- $\quad 448$

25-27 mo

$\begin{array}{ll}6-8 \text { mo } & 25-27 \\ 448 & 351\end{array}$

3. Knox \& Oliveira, 1980 [55]... Table 2

-- number of microvessels /core field

3 mo $24 \mathrm{mo}$

-- cerebral cortex:

$143.3 \mu \mathrm{m} \pm 5.8$

$131.8 \mu \mathrm{m} \pm 5.7$

4. Wilkinson et al., 1981[45]... Fig. 3 (est'd)

-- number of vessel fragments/unit zone

$\begin{array}{cc}25 \mathrm{mo} & 31 \mathrm{mo} \\ 420 \pm 10 & 365 \pm 23\end{array}$

5. Knox, 1982 [56]...Table 4

-- numerical capillary density

3 mo

$25 \mathrm{mo}$

-- cerebral cortex:

$--\quad 73.95 \pm 2.47$

$68.05 \pm 4.84$

6. Casey \& Feldman, 1985 [57]... Table 1

-- mean volume density ratio

$6 \mathrm{mo} \quad 33 \mathrm{mo}$

-- medial nucleus of trapezoid body --

$0.0404 \pm 0.0023$

$0.0283 \pm 0.0015$

7. Buchweitz-Milton \& Weiss, 1987 [58] ... Table $2 \& 4$

-- average total capillary length

$8-10 \mathrm{mo}$

21-33 mo

-- cortex

$830.1+115$

$576.6+36$

-- all 6 brain areas

$836.6+54$

$592.2+22.2$

8. Jucker \& Meier-Ruge, 1989 [59] ... Table 1

-- no. of capillaries/measurement field

$\begin{array}{cc}18 \mathrm{mo} & 271 / 2 \mathrm{mo} \\ 38.6+1.6 & 27.4+2.6 \\ 32.0+1.2 & 24.4+1.7\end{array}$

-- parietal cortex, region 39

$32.0+1.2$

$24.4+1.7$

9. Jucker et al., 1990 [60] ... Tables 1a \& 1b

-- number of capillaries/field

$18 \mathrm{mo}$

$32.0 \pm 1.2$

$27 \mathrm{mo}$

-- hippocampus, CA1

$24.4 \pm 1.7$ 
-- parietal cortex, area 39

$$
\begin{array}{lll}
-- & 38.6 \pm 1.6 & 27.4 \pm 2.6
\end{array}
$$

10. Amenta et al., 1995a [53] ... Table 3

-- sum of capillary lengths/field

$\begin{array}{ccc} & 12 \mathrm{mo}(8) & 27 \mathrm{mo}(8) \\ -- & 190 \mu \mathrm{m} \pm 8 & 168 \mu \mathrm{m} \pm 6.3 \\ 148 \mu \mathrm{m} \pm 4.3 & 130 \mu \mathrm{m} \pm 4.7 \\ 170 \mu \mathrm{m} \pm 4.6 & 145 \mu \mathrm{m} \pm 6.1\end{array}$

-- frontal cortex

$$
170 \mu \mathrm{m} \pm 4.6 \quad 145 \mu \mathrm{m} \pm 6.1
$$

11. Amenta et al., 1995b [61] ... Table 4

-- capillary profile number

12 mo (10)

$122 \pm 7$

$130 \pm 6$

$113 \pm 6$
18 mo (10)

$71 \pm 4.3$

$82 \pm 5$

$58 \pm 4$

\section{MICE}

12. Biron et al., 2011 [34] ... text \& Table 4A

-- \% laminin fluorescent area/unit area --

-- hippocampus \& frontal cortex
5 mo (4)
$18-24$ mo (5)
$0.2321 \pm 0.0110$
$0.1882 \pm 0.001$

\section{MACAQUE MONKEY}

13. Burns et al. 1979 [62] ... Table 1

-- mean cross-sectional area of entire capillary in $\mu^{2}$

$\begin{array}{cc}4 \mathrm{yr}(3) & 20 \mathrm{yr}(5) \\ 31.6 \pm 8.1 & 22.8 \pm 2.2 \\ 36.6 \pm 10.4 & 20.7 \pm 3.5\end{array}$

-- frontal cortex

$36.6 \pm 10.4$

$20.7 \pm 3.5$

Key for Figs. $2 \& 3$ : Average age or range of ages in years above figures. Number in each group: ()$. \mathrm{d}=$ day, mo $=$ month 
TABLE 3. Cerebral capillary density in People

\section{Author/s}

14. Mann et al., 1986 [64]... Tale 7

-- capillary length sum/unit volume, $\mathrm{mm} / \mathrm{mm}^{3}$

-- frontal cortex:

15. Abernathy et al., 1993 [65]... Fig. 2 (est'd)

-- capillary length sum/unit vol., $\mathrm{mm} / \mathrm{mm}^{3}$

$\begin{array}{cc}30-50 \text { yr (4) } & 60-85 \text { yr (10) } \\ 1560 & 1100 \\ 2300-1100 & 1800-800\end{array}$

-- range

16. Bell \& Ball, 1981 [66]... Table 9

-- mean capillary density, $\mathrm{mm} / \mathrm{mm}^{3}$

av. 38 yr (5)

148

124

-- overall of 6 zones

17. Bell \& Ball, 1990 [67]... Table 2

-- av. capillary density, $\mathrm{mm} / \mathrm{mm}^{3}$

-- visual cortex, lamina 1

-- visual cortex, av. of 6 laminae

18. Buée et al., 1994 [68]... Table 1

-- \% capil. surface area of total cortical field area

-- cortical areas:

19. Fisher et al., 1990 [47] ...Table 2

-- vascular density index

-- prefrontal cotex:

-- basal forebrain:

12-54 yr (8)

141

251

$6-58$ yr (6)

965.5

Aged

$\underline{\mathrm{AD}}$

76-96 yr (9)

783.6

$1800-800$

$26.32 \%$

$18.95 \%$

124

111

101

102

99

97

206

212

-- hippocampus:

AD: av. 80 y r (7)

AD: av. 78 yr (5)

AD: $63-92$ (10)

$16.50 \%$

control: 23-90 yr (6)

94.6

86.8

82.3

94.3
AD: 76-92 yr (16)

75.4

42.7

50.2

83.1

20. Kitaguchi et al., 2007 [69] ... Fig. 2 (est'd)

-- capillary density in test grid method

-- frontal cortex

control: $73 \pm 4(6)$

28

28
AD: $79 \pm 12$

21

20 